\title{
Mali og indflydelseskontoen
}

\section{Tage Baumann}

\section{Mali-aktionen viser, at Danmark søger nye måder at gøre sig nyttig på for at købe indflydelse, men man må også finde nye stærke partnere at gøre sig nyttig for. Indflydelseskontoen er ved at flytte fra Washington til filialer i Paris og London}

Den 20. december vedtog FN's sikkerhedsråd en resolution, der åbnede for magtanvendelse i den afrikanske stat Mali.

Baggrunden var frygten for, at terrorgrupper med tilknytning til alQaeda-netværket var ved at bide sig fast i det krigshærgede lands nordlige del. Baggrunden var også frygten for, at den overgangsregering, der var skabt, og som forsøgte at hævde sin autoritet, var ved at blive undergravet af oprørske kræfter i Malis forsvars- og sikkerhedsstyrker. $\mathrm{Og}$ baggrunden var desuden frygt for en humanitær katastrofe og en destabilisering af "Sahel-regionen, den større Afrika-region og det internationale samfund i sin helhed" som det hedder i Sikkerhedsrådsresolution 2085.

Den 11. januar besluttede Frankrig at påtage sig den militære opgave sammen med andre europæiske og afrikanske lande til støtte for overgangsregeringens egne militære styrker. 16. januar besluttede Frankrig at sætte landstyrker ind.

Dagen før vedtog Danmark at sende et C-130 Hercules militærfly som logistisk støtte for de fransk ledede styrker.

Det skete på et tidspunkt, hvor den danske indsats i Irak var slut, og hvor den forsvarspolitiske dagorden var præget dels af den begyndende afvikling af indsatsen i Afghanistan dels af finanskrisen og de nedskæringer i forsvaret, som krisepolitikken nødvendigvis vil betyde.

\section{Obamas anden periode}

I det større perspektiv skete det få dage før, den amerikanske præsident Barak Obama blev indsat i sin anden præsidentperiode, og under indtryk af den nyorientering af den 
amerikanske sikkerheds- og forsvarspolitik, han havde taget hul på i sin første periode, og som kort fortalt betyder tre vigtige ændringer:

For det første betyder den stigende internationale tyngde, som Kina får økonomisk, politik og militært, at USA er nødt til at fokusere på forholdet til Kina og på magt- og samarbejdsforholdene i Asien og Stillehavsområdet.

For det andet betyder den amerikanske energipolitiske udvikling, at USA i stigende grad bliver uafhængig af energiimport og derfor mindre følsom over for udviklingen i de tunge energiproducerende regioner som - og især - Mellemøsten. USA's opmærksomhed bindes med andre ord ikke længere i samme grad i regionen af strategiske grunde, omend det af politiske grunde vil vare længe, før USA fjerner sin opmærksomhed fra Israels sikkerhedsproblemer.

Og for det tredje betyder den begyndende afvikling af ISAF-styrkens engagement i Afghanistan, at USA har politisk råd til at flytte fokus fra Europa og i stedet bruge flere kræfter på Stillehavsområdet, Kina (og Indien) og det asiatiske område.

Forsvarspolitisk har den udvikling været i gang i nogle år og resulteret i nye eller forbedrede baseaftaler med lande som Australien og Singapore, men her i Obamas anden præsidentperiode siger folk med forstand på de dele, at både diplomatiet og den økonomiske politik må følge op på den forsvarspolitiske nyorientering, således at også en aktiv amerikansk udenrigs- og sikkerhedspolitik vil bruge kræfter på at engagere de store vækstøkonomier Kina og Indien på bekostning af det amerikanske engagement over for Europa.

Det var næsten som en besværgelse at høre europæiske ledere forsøge at fastholde amerikanernes engagement i Europa - og næsten lige så rituel en besværgelse at høre USA's vicepræsident Joe Biden forsøge at berolige europæerne - på dette års sikkerhedspolitiske konference i München, det, der en gang hed Wehrkundetag, i begyndelsen af februar.

\section{Mali som dansk prøve}

Få dage efter den danske beslutning om at være med i Mali med lufttransport og i en pause på konferencen spurgte jeg forsvarsminister Nick Hækkerup, om Mali-operationen så var en prøve på, hvordan Danmark vil udmønte sin aktivistiske udenrigspolitik i fremtiden, hvilket han energisk bekræftede.

Det ligger i forlængelse af den logik, som drev dansk udenrigspolitik til operationer som Golfkrigen, Kosovo, Afghanistan og ikke mindst Irak. Med undtagelse af Kosovo, som kunne få direkte betydning for hele Europa og altså også for Danmark, så var dansk område, dansk befolkning og dansk handlefrihed 
ikke umiddelbart truet af udviklingen i de områder, vi valgte at sende kampstyrker til, med og uden FNmandat.

Vi gjorde det af hensyn til det, der er blevet beskrevet som 'indflydelseskontoen i Washington'. Med andre ord den tanke, at Danmark som et lille land i en verden, der ikke længere er præget af den kolde krig og Danmarks relative strategiske betydning for den vestlige alliance som frontlinjestat i den krig, må lede efter andre måder at øge sin vægt på $\mathrm{i}$ international sammenhæng.

Det kunne være sket på flere måder, men skiftende regeringer valgte at forsøge at øge dansk vægt i international politik og diplomati ved at knytte sig helt tæt til den stærkeste af de tilbageværende stormagter supermagten og mono-polen USA.

Hvad vi gjorde i Kosovo, Irak og Afghanistan gjorde vi med et øje rettet mod reaktionen i Washington. Håbet var at blive styrket af amerikansk velvilje og samarbejde, også, og måske især, over for tredjelande, i NATO, i FN og i EU. Vi håbede at vinde vægt over for andre som dem, der blev modtaget på højeste niveau i Washington, som dem der havde denne verdens virkelige magthavers øre og bevågenhed.

Om det regnestykke gik op er ikke temaet her.

Det er derimod de ændrede rammebetingelser for den danske 'indflydelsesstrategi', som afslutningen af Afghanistan-operationen, spare- krav som følge af finanskrise og nyorienteringen af den amerikanske udenrigs- og sikkerhedspolitik betyder.

Og hvorfor de ændrede betingelser $g \varnothing r$ beslutningen om at være militært til stede i Mali med lufttransport kapaciteter logisk.

\section{I krig efter krig}

Den konservative Poul Schlüters regering sendte et dansk orlogsfartøj i daglig tale et krigsskib - ud i den første Irak-krig (Golfkrigen), en krig USA stod i spidsen for med rygstød i FN-pagten, men uden NATO-deltagelse.

Den socialdemokratiske Poul Nyrup Rasmussens regering sendte Danmark i aktiv operation i Bosnien med, og i Kosovo uden, FN-mandat, men med NATO-deltagelse.

Den liberale Anders Fogh Rasmussens regeringer sendte Danmark i krig i Afghanistan med støtte i FNpagten, fra 2006 med NATO-deltagelse, og i Irak uden FN-mandat og uden NATO-deltagelse.

Hans liberale efterfølger Lars Løkke Rasmussens regering sendte Danmark i krig i Libyen på et (over) fortolket FN-mandat og i første omgang uden, senere med NATOs deltagelse og et stort europæisk aftryk.

Mens den nuværende socialdemokratiske Helle Thorning Schmidts regering så har sendt Danmark i militær aktion på FN-mandat i Mali, en aktion uden NATOs deltagelse men 
ligeledes med et stort europæisk aftryk.

Det afspejler rammebetingelser, der er under hastig forandring.

Den dybeste ændring er den amerikanske nyfokusering mod det asiatiske område, som betyder to ting: dels at europæerne må vænne sig til selv at skulle klare den praktiske udmøntning af deres militære ambitioner eller ambitioner om en aktivistisk udenrigspolitik, dels at amerikanerne har mindre brug for europæerne, som ikke har så meget at tilbyde i et Stillehavs-asiatisk scenario men fortrænges af mere oplagte samarbejdspartnere for USA: Australien, Japan, Sydkorea, Singapore...

Den mest iøjnefaldende ændring er finanskrisen, som umiddelbart slår igennem som store besparelser på forsvarsbudgetterne hinsides den oprindelige forestilling efter den kolde krigs ophør om en fredsdividende, der kunne kanaliseres ind $\mathrm{i}$ civilsamfundet.

Finanskrisen og de afledte forsvarsbesparelser betyder helt konkret, at et lille land som Danmark må indse, at langvarige og omkostningskrævende store operationer som Afghanistan-krigen ikke længere er en realistisk model. For slet ikke at tale om at føre to sådanne operationer (Irak og Afghanistan) samtidig.

Så hvis vi vil være 'nyttige' for andre, til gavn for en dansk 'indflydelseskonto' må vi finde nye måde at gøre nytte på. Billigere måder.
Det kan være det, Mali-bidraget er en prøvekørsel på. Lufttransport er et af de områder, Danmark har valgt at vægte som en kernekapacitet.

Også det overstiger ganske vist vores nationale muligheder, men svaret er samarbejde, og slagordet er smart defence. I praksis udformet som et dansk-norsk-svensk samarbejde om på sigt at opbygge en større flåde af lufttransportfly, indtil videre netop af C 130 Hercules typen, som så kan stilles til rådighed i operationer af Mali-typen til aflastning og nytte for de lande, der tager sig af de egentlige kampoperationer.

\section{Smart defence}

Det er ikke uproblematisk og som mange af smart defence-projekterne hæmmet af suverænitets-overvejelser, som det vil føre for langt at gennemgå i denne artikel, men som findes beskrevet i flere forskningsrapporter fra Center for Militære Studier på Københavns Universitet, som forsvarsministeren og forsvarsforligspartierne har bedt om at udrede problemerne omkring smart defence.

Hercules samarbejdet er bare et eksempel. Danmark har besluttet at spille en aktiv rolle i en lang række smart defence-samarbejder, dels for at kunne opretholde kapaciteter, vi ikke længere har råd til selv, dels for at spare penge på de kapaciteter, vi allerede har besluttet, at vi vil opretholde under alle omstændigheder.

Det her giver økonomisk mening, 
fordi alle landes forsvarsbudgetter er under pres, og som Hercules-eksemplet viser, er Danmark ikke begrænset til samarbejde alene med NATO-partnere, men kan søge andre nære politiske venner, som svenskerne, i den her type samarbejde.

Hercules samarbejdet er et eksempel på, hvordan Danmark under de ændrede rammebetingelser kan opretholde kapaciteter, der kan være nyttige for andre i fremtiden, uden at sprænge de økonomiske rammer som Folketing og befolkning er parat til at acceptere for det danske forsvar.

Problemet for den danske 'indflydelses-politik' i Washington er, at netop Washington har mindst brug for smart defence-projekter. For amerikanerne kan, som de eneste, selv hele det militære spektrum. For amerikanerne er smart defence måske 'nice to have' men ikke 'need to have', og det påvirker naturligvis også den pris i form af politisk-diplomatisk velvilje, som amerikanerne er parate til at betale for at finde samarbejdspartnere til militære og forsvarsindustrielle projekter. Fremtiden er den modsatte: det er europæerne, der skal gøre sig lækre over for amerikanerne, og som derfor også må betale politisk og diplomatisk for at holde amerikanerne inde i større militære projekter.

Der er vi ikke endnu, men ude i horisonten ses den fremtid allerede. Så længe Afghanistan-operationen er i gang, bliver den udvikling ikke helt tydelig, men senest efter 2014 måske før med det kapløb mod udgangen som er i gang, også fra dansk side - må europæerne tænke alvorligt over, hvad de vil gøre, når de en dag er alene hjemme så at sige, fordi den amerikanske far er taget til Asien.

Det ved de europæiske ledere, derfor en vis europæisk nervøsitet på dettes års München-konference. Af samme grund forbereder EU et særligt topmøde i slutningen af året med kun et emne på dagordenen, nemlig sikkerheds- og forsvarspolitikken. Det bliver første gang nogensinde, at EU holder sådan et topmøde, og for Danmark kan det blive besværligt på grund af det danske forsvarsforbehold i EU.

Det aktuelle ambitionsniveau ser ud til at gøre sådanne danske trængsler overkommelige, for i første omgang kommer diskussionen nok til at dreje sig om, hvordan EU og NATO kan få et samarbejde til at fungere. En dagsorden som Danmark kan gå helt ind for.

\section{Den nye assymetri}

Men på lidt længere sigt betyder den nye assymetri, at USA kan klare sig selv, mens ingen af europæerne kan - at Danmark ikke bare skal finde nye måder at gøre sig nyttig på for at købe indflydelse, men også skal finde nye stærke partnere at gøre sig nyttige for.

Der er ikke så mange svar, ja i 
grunden kun et: de europæiske stormagter, europæisk NATO og EU.

Måske var det en overvejelse, der spillede ind, da Danmark så hurtigt og næsten uden betingelser sagde ja til at være med i aktionen i Libyen. En aktion som fra start hverken var amerikansk eller NATO-drevet, men drevet af de europæiske stormagter Frankrig og Storbritannien, og først som en nødvendig eftertanke blev forankret i NATO og med afgørende amerikansk støtte.

Man kan måske se det danske Libyen-bidrag som en trædesten på vejen til at gøre danske hoser (militær) grønne over for andre end USA i forsøget på at flytte en del af den danske indflydelseskonto fra Washington til filialer i Paris og London. I den logik er Mali-operationen prøven på, om den model kan flyve også i ren europæisk sammenhæng. Om vi med andre ord kan købe os indflydelse i Europa gennem militært aktivistiske bidrag til europæiske aktioner.
Et mål for de danske bidrag i Irak og Afghanistan var at få adgang til den amerikanske regering på højst muligt niveau - med modtagelser i Det Hvide Hus, State Department og Pentagon som førstepræmier. Men det kan næppe være målet med danske bidrag til europæiske aktioner, for de europæiske ledere har Danmark i forvejen adgang til på højeste niveau gennem Det Europæiske Råd, altså topmøderne i EU og de hyppige ministerrådsmøder.

Det internationale indflydelsesspil er et andet i europæisk sammenhæng end i transatlantisk, og spørgsmålet er, om der er et dansk regnestykke her, der overhovedet kan gå op.

Hvis man altså i det hele taget er til teorien om indflydelseskonti. Det er langtfra alle.

Tage Baumann er journalist og mangeårig sikkerheds- og forsvarspolitisk medarbejder ved Orientering på P1 samt programmets tysklandsmedarbejder. 